\title{
What do They Need to Know?
}

\author{
Libby V. Morris
}

Published online: 31 January 2013

(C) Springer Science+Business Media New York 2013

This year, for the first semester in over two years, I will be teaching in the Institute of Higher Education's executive doctoral program in higher education administration, http://ihe.uga.edu/ graduate-programs/edd. Based in Atlanta, the program offers a concentrated two-year program format for middle and upper-level administrators who wish to gain an in-depth understanding of postsecondary education in the United States and abroad. In fact, one of the distinguishing features of the program is the focus on international higher education and the study abroad programs offered each summer at the Center for Higher Education Policy Studies (CHEPs) at the University of Twente in the Netherlands, http://www.utwente.nl/mb/cheps/ and in China at Beijing Normal University's Institute of International and Comparative Education and at Peking University. Professor Sheila Slaughter and I share the courses this term, and we have had an interesting dialogue around the following question. "What do they need to know?" Our focus will be on the intersections of programs, delivery, marketization, stratification, and access. It's a big umbrella with lots to consider.

This question resonates throughout higher education. Several decades ago, in 1949, Robert Tyler, a curricular leader in higher education, posed significant questions in the book entitled Basic Principles of Curriculum and Instruction. What purpose shall the curriculum serve? What experiences should the institution and its faculty provide to meet these expressed purposes? Since that time, and even before, faculty, governing bodies, and professional associations have struggled to answer those questions. Increasingly, colleges and universities address the expectations and demands of internal and external constituents with money and power to drive educational agendas.

During the 1980s critiques of U.S. higher education increased in frequency and included often strident pronouncements. A Nation at Risk (1983), Involvement in Learning: Realizing the Potential of American Higher Education (1984), and Integrity in the College Curriculum (1985), to name only three, stressed the need for curricular reform and called on colleges to deal with problematic issues in curricular coherence, accessibility, and quality. Other reports claimed the supremacy of the humanities over the voices for general education and marketplace skills. For example, To Reclaim a Legacy: A Report on the Humanities in Higher Education (1983) along with a number of other reports from the National Endowment for the Humanities emphasized the importance of the liberal arts as the core of a college education.

L. V. Morris $(\bowtie)$

Institute of Higher Education, University of Georgia, 102 Meigs Hall, Athens, GA 30602-6772, USA

e-mail: lvmorris@uga.edu 
However, after years of debates and reports, the issue of the role and purpose of undergraduate education could not be settled once and for all. Student needs and interests, workforce demands, the diversity of courses, and the variety in institutional types do not lead to a common curriculum with a single set of goals and objectives for all students everywhere. Unlike the early colleges in the first century of U.S. higher education, a common, comprehensive curriculum is virtually impossible in light of the rapid growth of knowledge in disciplines, sub-disciplines, professional fields, and new interdisciplinary areas of study.

Rather, in recent decades, a focus on competencies and standards began to replace the focus on content. Reports such as Involvement in Learning (1984) stressed the importance of institutions setting standards for performance and awarding degrees based on the measurement of those standards. Institutions would be guided by their expectations for what constitutes college-level learning. Common competencies included critical thinking, communication, and higher level skills in reading and writing. Accompanying this shift from content to competencies was the growth of the assessment movement and the discussion of the "value-added" by education. A nationwide industry of measurement and testing grew around this institutional need to demonstrate and measure outcomes of student learning.

Now, the national focus has shifted with full force to another imperative, college completion. Following a period of "opening the door," we have now entered a period of accountability for retention and graduation, as national imperatives. The importance of the completion agenda, along with state-level data to support the claims, is clearly enunciated in the documents and reports of the Lumina Foundation, http://www.luminafoundation.org/states_landing/a_stronger_ nation_through_education/. The "Big Goal" as explained in A Stronger Nation through Higher Education (2012) is to reach $60 \%$ of Americans holding high-quality post-secondary degrees, certificates, or other credentials by 2025 . Added to the reports and concerns about content, affordability, accessibility, and student learning is an intensified focus on college completion. Lumina has noted that the U.S. is falling behind its global competitors; where we once ranked first in youth with a college degree, we now rank $10^{\text {th }}$ globally. In step with the Lumina report is Complete College America (http://completecollege.org/), a non-profit organization established in 2009 that now boasts more than 30 states in its "Alliance of States." Members commit to setting completion goals, developing action plans, and collecting and reporting common measures of progress. The state of Georgia is a member of the alliance, and the University System of Georgia has required all of its 35 public colleges and universities to develop college completion strategic plans. Of course, the public research universities that have the most selective admissions policies also have the highest graduation rates, exceeding $80 \%$. The less selective, open-door institutions are much lower, sometimes with only 1 in 5 reaching graduation. So, as a system we have challenges ahead--in building responsive programs, keeping college accessible while graduating higher percentages of students, educating more people in post-secondary education (retention alone will not be enough to reach Georgia's target number of post-secondary graduates), maintaining quality and ensuring competence, serving workforce needs, while not forgetting that we all come from different cultural, historical, and geographical roots, requiring a concentrated focus in general education so as to develop an appreciation for diversity and diverse viewpoints.

$\mathrm{Oh}$, the tasks are daunting! We must not water-down programs to reach a number, nor can we satisfy the "should" of every constituent group. Now more than ever higher education faculty members must give deliberate thought to education overall and its role in the society. What type of knowledge and skills and attitudes will lead to a satisfying and successful life as an adult in the complexity of a high-technology, information-rich 21 st century?

Now, back to the course planning.... what should they learn and how? What do they need to know? 